\title{
WHEN SINKHOLES BECOME LEGAL PROBLEMS
}

\author{
Steven T. Miano \\ Hangley Aronchick Segal Pudlin \& Schiller, One Logan Square, 27th Floor, Philadelphia, PA, 19103, United States, \\ smiano@hangley.com
}

Peter V. Keays

Hangley Aronchick Segal Pudlin \& Schiller, One Logan Square, 27th Floor, Philadelphia, PA, 19103, United States, pkeays@hangley.com

\begin{abstract}
Sinkholes can cause property damage, injury to people and harm to the environment. It is therefore not surprising that myriad legal issues arise in the context of sinkholes and the actual and potential harms they present. This paper will focus on those legal issues and will include a discussion of potential causes of action (i.e., legal claims), both under statutory laws (e.g., state laws like in Pennsylvania under which sinkholes can be deemed a nuisance) and common law (i.e., claims derived from longstanding judicial precedent), and available damages (i.e., monetary compensation) and other remedies. Mining activities and water supply wells for industrial, commercial and residential uses, which pump groundwater in karst and other sinkhole prone areas, are often a direct cause of sinkholes. Yet most government agencies regulating mining and other related industries are ill-equipped, either technically or politically, to manage the potential, and in some cases, inevitable damage. Few, in fact, recognize the direct relationship between activities they typically permit, the formation of sinkholes, and the resulting harms.
\end{abstract}

This paper will also discuss both bringing a case for sinkhole remediation (direct lawsuits and mining permit appeals) and defending sinkhole-related claims. Because cases involving karst terrain and sinkholes tend to turn on the presentation of highly technical scientific principles, educating the court is critical, as is the experience and expertise of a top-notch expert witness. This paper will discuss the ways to effectively present such cases in court, including the presentation of technical witnesses/ experts.

Two case studies will be examined. One case involves a school and a neighboring quarry, in which the court found that a quarry was the direct cause of sinkholes opening in the surrounding area. As a result, the court held that the quarry constituted a nuisance, and therefore denied a permit extension allowing further mining. Another case study will examine sinkholes opening near a major roadway in an area where no mining is known to have occurred.

\section{Introduction}

Sinkholes can lead to significant physical, economic, and environmental harm. A party impacted by sinkholes may have several viable causes of action against other parties and, in certain circumstances, legal recourse against government agencies. This paper is intended to provide a general overview of the legal landscape surrounding sinkhole litigation, including preventative measures, claims, defenses, and available remedies.

\section{Overview of Common Legal Issues Implicated by Sinkholes}

The common thread running through the wide range of legal issues that arise surrounding the threat and occurrence of collapse sinkholes can be boiled down to one word: causation. The question of who or what caused the sinkhole at issue is the lodestar of any claim, defense, or regulatory or enforcement action. Given the highly technical issues involved, and the fact that the conditions leading to the opening of a sinkhole are subterranean (and thus unobservable by a judge or jury), the responsibility of proving or disproving the alleged cause of a sinkhole falls to expert witnesses.

\section{Bringing Legal Claims Related to Sinkholes}

A party may bring a number of tort claims (i.e., claims based on some type of harm caused by another person or party) related to the occurrence of collapse sinkholes depending on the circumstances presented and the party's ultimate objective. These claims overwhelmingly arise under state law rather than federal law. This paper is not intended to describe in detail the law of any particular state, but rather to provide a general overview of the types of claims that are most commonly invoked in sinkhole cases. Fortunately, most state law claims are derived from the common law, and as a result, the causes of action are the same or very similar from state to state.

Negligence is one of the most common claims asserted by parties affected by sinkholes. In order to prevail on a negligence claim, a plaintiff must show that the defendant owed a duty to the plaintiff, that the defendant breached that duty, and that the breach caused an injury 
to the plaintiff. ${ }^{1}$ When it comes to sinkhole litigation, technical considerations can inform all elements of a negligence claim. For example, the landowner often has a duty to make the premises safe for other people who enter the property with the landowner's express or implied permission. The extent of the owner's obligation is usually dictated by the type of people who may foreseeably enter the land, the foreseeable uses of the land, and what the owner knew or should have known about his or her land. This duty generally includes "inspecting the premises to discover possible dangerous conditions of which the owner/occupier does not have actual knowledge, and taking reasonable precautions to protect invitees from dangers foreseeable from the arrangement or use of the premises." ${ }^{.2}$ This speaks to one of the most fundamental concepts underlying many of the legal issues addressed herein. Namely, that the law is concerned not only with what a party actually knew, but also with what a party should have known given the particular circumstances. In the context of sinkhole litigation, this legal concept, known as constructive knowledge, prevents landowners from simply hiding behind a veil of willful ignorance.

In the case of Lore v. Suwanee Creek Homeowners Association, a sinkhole opened in a "recreation area", and the plaintiff-after repeatedly informing the landowner about the sinkhole-was injured when the ground collapsed from underneath her as she was standing approximately four feet from the sinkhole. ${ }^{3}$ The appeals court held that the owner had a duty to inspect the sinkhole and the surrounding area to determine whether it posed a danger, and remanded the case to the trial court to determine whether the landowner breached that duty by failing to inspect and/or by failing to take reasonable steps to protect individuals from foreseeable dangers. Thus, technical knowledge and expertise can be critically important in determining not only when a duty arises, but what actions must be taken to satisfy that duty and mitigate the chance of harm. The same is true with respect to claims related to sinkholes occurring on adjacent land.

Failure to comply with guidelines or accepted procedures can serve as evidence of breach and causation. For instance, in Widner v. King County, defendant King County filed a motion for summary judgment (i.e., a motion arguing that there are no disputed factual questions and that the court can reach a legal conclusion and resolve the case without proceeding to trial) against plaintiffs' nuisance claims on the bases that (1) the plaintiff had no evidence that the County's construction of a temporary roadway caused sinkholes on plaintiffs' property, and (2) the County did not owe plaintiffs a duty of care because the damage to the plaintiffs' upland property was not foreseeable. ${ }^{4}$ The trial court denied the motion and allowed the matter to proceed to trial on the basis of plaintiffs' expert report. In his report, the expert opined that had King County conducted a pre-construction analysis in accordance with the parameters set forth in the County's Guidelines for Bank Stabilization Projects, the damage to plaintiffs' property would likely have been both foreseeable and avoidable. ${ }^{5}$ The court denied the County's motion, ruling that the expert's opinion was sufficient to create questions of fact as to both causation and duty.

Plaintiffs also often rely on the tort of trespass to redress harm caused by sinkholes. Many jurisdictions recognize more specific causes of action derived from trespass that are directly applicable to sinkholes, including trespass by subsidence, trespass by water, and inadequate subjacent support. The elements of trespass by subsidence under Kansas law are representative of trespass-related causes of action. In order to prevail on a claim of trespass by subsidence under Kansas law, a landowner must show "(1) [that] the defendant committed an act that, (2) resulted in an intrusion upon the surface of the land, (3) which interfered with the surface owner's right to exclusive possession and enjoyment of the land. ${ }^{.6}$ Here, too, there must be a causal connection between the defendant's act and the intrusion (i.e., the sinkholes). Although the family of trespass-based claims are viable in most jurisdictions, they are increasingly viewed as antiquated and disfavored.

Nuisance, which has two distinct yet often related dimensions, is another cause of action that is commonly invoked in sinkhole litigation.

Private nuisance is a non-trespassory invasion of another's interest in the private use and enjoyment of land. Liability for private nuisance arises where there is interference with a plaintiff's use or enjoyment of the land, and that interference is both unreasonable and substantial. Here, as with negligence, it must be shown that the defendant —or land or property that the defendant owned or controlled-caused the interference. ${ }^{7}$

Public nuisance arises where there is an unreasonable interference with a right (not necessarily the use and enjoyment of land) common to the general public. State and local governments are empowered to abate public nuisances. Most jurisdictions do, however, also permit private parties to bring claims seeking damages where a public nuisance injures their property, but only if the nuisance is "specially injurious" to that party, meaning that the nuisance affects that party differently and more 
severely than the general public. ${ }^{8}$ Public nuisance is addressed at greater length in Case Study One, below.

In addition to tort claims, sinkholes can give rise to contract claims and liabilities. Thorough due diligence is critical, particularly in karst regions and other sinkholeprone areas. This is true not only for buyers, who may ultimately be saddled with a sinkhole-laden property (and the liability that may accompany it), but also for sellers, to whom a comprehensive understanding of the site is invaluable when it comes to making representations and warranties in a land contract. The failure of a party (or a party's expert) to identify areas that are particularly prone to sinkholes can have significant consequences on the questions of who bears the lability for potential harm that may arise if sinkholes open and who is responsible for repairing any sinkholes that open. Case Study Two, below, addresses several contractual issues that can arise when sinkholes open.

Parties aggrieved by the occurrence of sinkholes may also have statutory claims and other forms of recourse, possibly through or against a state regulatory agency. This route is generally more effective when a party is seeking injunctive relief (i.e., an order to do something or stop doing something) as opposed to monetary damages. Various statutes and regulations may contain footholds that can be used to force agencies or private parties to take action to prevent future sinkholes. For example, state statutes commonly declare certain conditions to be public nuisances, and then impose a duty upon a state agency or agencies to mitigate or abate such nuisances. Pressure can be brought to bear upon those agencies, and, in many situations, parties may compel an agency to act by seeking a writ of mandamus (i.e., a court order requiring a government agency or official take a particular action) from a court with proper jurisdiction. Because many of the activities that commonly cause sinkholes are associated with industries that are subject to significant health, safety, and environmental regulation, and thus require various permits in order to operate, the permitting process can be an effective means to combat sinkholes. Permitting is a public process. Third-parties are afforded the opportunity to comment on proposed permits, and the permitting agency is required to consider those comments. If the permitting process itself does not bear fruit, an interested third-party may then challenge the permit in court or before some form of administrative tribunal. Case Study 1, below, illustrates the effective use of several of these tactics.

\section{Defending Sinkhole-Related Claims}

Issues of causation, knowledge, and the reasonableness of an action (or lack of action) under a particular set of circumstances also dominate the defense against sinkhole-based claims. Technical data and expert opinions are therefore also critically important when defending against sinkhole-based claims.

The expiration of the applicable statute of limitations (i.e., a set period of time after which a claim can no longer be brought) is one of the most common defenses against sinkhole-related tort and contract claims. Causation and other technical questions are often critical components of a statute of limitations defense. In general, a statute of limitations only begins to run at the moment that a claim can first be brought (this is known as the "accrual" of a claim), which is not always the same moment that the underlying act occurred. For example, with trespass to land, after the defendant commits the act that gives rise to the claim, that claim does not accrue until the subsidence or other intrusion occurs and interferes with the landowner's property rights. Where the cause of a sinkhole is reasonably ascertainable through investigation, the statute of limitations will not be tolled. ${ }^{9}$ Thus, causation is a critical question to both parties, as is the question of what is "reasonably ascertainable." Once a party knows or has reason to believe that a sinkhole was the result of another person's action, the statute of limitations "clock" begins to run.

Compliance with the law, including environmental laws and permitting requirements, is not a defense to most tort claims, including nuisance and negligence. ${ }^{10}$ However, compliance with the law does tend to show the lack of willful or malicious misconduct that is generally required to support an award of punitive damages (i.e., additional money awarded to punish a defendant for particularly egregious behavior). ${ }^{11}$ In fact, courts have recognized that punitive damages are "improper where a defendant has adhered to environmental and safety regulations." 12

Evidence of alternative or additional causes of sinkholes may also serve to negate a plaintiff's evidence related to causation. Such evidence is particularly useful when it suggests that the plaintiff herself may have caused, or contributed to the conditions that caused, the sinkhole. The impact of this type of evidence varies significantly depending on which state's laws govern in a particular case. At one end of the spectrum, certain states do not allow a plaintiff to recover any damages if he or she is found to be at all responsible for the harm underlying his or her claim. Other states will reduce the amount of a plaintiff's damages commensurate with the percentage of responsibility the plaintiff is found to bear. In other states, 
the plaintiff's damages will be reduced commensurate with the plaintiff's responsibility, unless plaintiff is found to bear the majority of the responsibility for his or her own injury, in which case no damages may be recovered. Regardless of the jurisdiction, evidence of alternative or additional causes of sinkholes is critically important in sinkhole litigation.

It is worth noting that there is rarely (if ever) direct evidence (i.e., evidence that directly supports the truth of an assertion) of sinkhole causation. Such evidence is always circumstantial (i.e., evidence that supports the creation of an inference that in turn supports the truth of an assertion, for example, the presence of the victim's blood on the defendant's shirt), and the thoroughness, documentation, and credibility of experts is of critical importance, as is the manner in which experts present these highly technical theories of causation - particularly if there is a jury involved. It is important to address contributing factors or alternate theories of causation squarely and honestly. Although experts are retained by and testify on behalf of their clients, it is not their responsibility to openly advocate on their client's behalf. This is a fine line to walk. While it's important for an expert to approach his or her work with their client's interest at the forefront of his or her mind, and to present their opinions in the light most favorable to the client's position, an expert must also be careful not to wander too far into the realm of advocacy, lest they lose credibility in the eyes of the judge or jury.

\section{Relief Available for Sinkhole-Related Claims}

Courts generally have considerable discretion in crafting the relief awarded to plaintiffs that succeed in proving the various sinkhole-based claims. Damages may be awarded to compensate the plaintiff for personal injury, property damage, and the foreseeable consequences arising from the occurrence of sinkholes. However, in a disproportionate number of cases - particularly those involving successful nuisance claims - parties seek and courts award some form of injunctive relief. Courts generally have wide discretion to issue injunctions, which can be either affirmative (i.e., ordering a party to act) or negative (i.e., ordering a party to refrain from acting). Courts generally try to issue narrow injunctions targeted at the behavior or condition that is causing the harm. ${ }^{13}$ These forms of relief may also be available in regulatory and statutory cases.

\section{Case Study One}

This case study involves a private boarding school located in a rural area and a limestone quarry located directly next to the school. The school and the quarry are located in karst terrain.

Mining has been occurring on the quarry property since the $19^{\text {th }}$ Century, but it wasn't until the 1960 s that mining began at depth, which required the dewatering of the quarry pit. The state regulatory agency issued the quarry its first mining permit in the mid-1970s. Although the permit approves mining to a depth of $-200^{\prime}$ MSL, the agency has required the quarry to apply for separate "depth corrections" in order to mine progressively closer to that depth. In July 2011, the agency issued the quarry a depth correction allowing it to mine to a depth of -170 , MSL; the previous depth correction, issued in 2007, allowed the quarry to mine to -120 ' MSL. Following the issuance of the most recent depth correction, the quarry was pumping 2-4 million gallons of water per day from the quarry pit.

In 1989, collapse sinkholes began to open on the school's campus. The sinkholes ranged from several feet across to nearly a quarter an acre, most exceeding 20 feet across. Between 1989 and 2014 at least 29 sinkholes opened on the school's campus, and at least 10 sinkholes opened on neighboring properties, the largest of which was 150 feet long, 75 feet wide, and 15-20 feet deep. Over the course of this time period, wells on the school's campus began to go dry. Deeper wells were drilled, only to dry up a few years later. In addition, the creek that historically ran across the campus and the quarry property ran dry; what little flow remained was sporadic and was drained by a swallet that formed on the quarry's property, not far from the school's property line.

The sinkholes presented an enormous danger to the safety of the students, faculty, staff, and visitors, and posed a potentially existential problem for the school. Around the time that the quarry applied for its most recent depth correction in 2008, the school retained two experts - a licensed professional engineer and a $\mathrm{Ph} . \mathrm{D}$. in geology - to investigate the potential cause or causes of the sinkholes, and to make recommendations as to how future sinkholes might be prevented. Based on the investigation of these experts, which revealed that the dewatering of the quarry pit was causing the sinkholes and that deepening the quarry pit would promote continued sinkholes on the campus, the school opposed issuance of the depth correction. The agency limited its review to the marginal impact of adding 50 feet to the quarry, as opposed to the continuing impact of the ongoing dewatering of the quarry (an approach 
that was later held to be improper and unlawful). After concluding that the school failed to show that the depth correction would exacerbate the sinkhole problem, the agency issued the depth correction in 2011. The school appealed the depth correction to a state administrative court.

Not surprisingly, the issue of causation was at the heart of the school's appeal, which was ultimately resolved in the school's favor after a two-week trial, most of which was focused on conflicting expert testimony. The court ultimately concluded that-because the quarry's dewatering had substantially lowered the groundwater under the school, which, given the underlying karst features, resulted in the sinkholes - the quarry's dewatering of the quarry pit is the "overriding cause" of the sinkholes. ${ }^{14}$ At trial, the quarry and the agency's experts offered several alternate theories of sinkhole causation, including flooding caused by heavy precipitation and the school's development activities on its campus, which the court rejected. The court found that continued dewatering will further depress groundwater levels below the school, and - crediting the opinions of the school's expert witnesses - found that "dewatering of the quarry is directly resulting and will continue to result in the hazardous formation of collapse sinkholes." ${ }^{\prime 15}$

The court anchored its legal conclusions on various provisions of the state's noncoal surface mining act and related regulations. Citing the stated purpose of the act, which includes "preventing and eliminating hazards to health and safety," 16 the court pointed to the requirement that no permit may be issued unless the applicant affirmatively demonstrates, among other things, "that it will ensure the protection of the quality and quantity of surface water and groundwater, both within the permit area and adjacent areas, as well as the rights of present users of surface water and groundwater." ${ }^{17}$ Citing a number of statutory and regulatory provisions, the court affirmed that the agency not only has the authority to deny the depth correction "if continued mining is causing unavoidable and serious harm to health and safety," but also the "duty to ensure that mining can be performed without undue risk to health, safety, and welfare." 18 The court ruled that by issuing the depth correction the agency acted unlawfully and unreasonably by enabling a serious hazard to continue unabated. The court also rejected the standard for reviewing the quarry's application, stating that "the question is not whether the limited subject of the revision can be safely accomplished," but rather "whether the project as a whole, as revised, can be safely accomplished." 19 Invoking a statutory provision that declares "any condition that creates a risk of...subsidence, cave-in, or other unsafe, dangerous or hazardous condition" ${ }^{20}$ to be a public nuisance, the court ruled that the quarry is creating a public nuisance. The court also invoked the agency's statutory duty to abate and remove public nuisances. ${ }^{21}$

In the wake of the court's decision, the agency required the quarry to begin reclamation and to submit a reclamation plan and timeline that was driven by the time needed to restore the groundwater and abate the nuisance, rather than the time needed to extract the remaining mineable reserves. The quarry's failure to comply resulted in the issuance of an order that imposed various requirements and restrictions upon the quarry, most notably, a daily pumping limit of 500,000 gallons. That order was recently upheld by the court.

This case exemplifies the critical role that expert witnesses can play in sinkhole litigation. As the court wrote: "the School assembled a top-notch team of experts for evaluating the karst geology of the [basin] and the hydrogeologic connection between the quarry's dewatering and the sinkhole development on the School's campus, the key issues in the case." ${ }^{\prime 22}$ This case also illustrates that statutes and regulations and the permitting process can be powerful tools that a party can use to combat sinkholes, even in cases where the government agency entrusted with enforcing those laws fails to do so.

\section{Case Study Two}

This case study pertains to an ongoing dispute arising out of a lease renewal agreement between a state roadway commission and a concessionaire for a rest area on the roadway. A number of years after the lease was executed, several sinkholes opened on the property, none of which damaged existing structures. Each party has taken the position that, under the lease, the other party is responsible for the costs associated with repairing the sinkholes. The parties are currently in the process of negotiating in hopes of avoiding litigation. The lease does not specifically address sinkholes, but there are several relevant provisions that have become the focus of the parties' negotiations. The issues include the question of what constitutes a pre-existing condition, and whether sinkholes are "environmental" in nature. Again, the question of causation and underlying conditions are front and center. Technical experts are critical to the analysis.

\section{Conclusion}

Sinkholes have the potential to create significant and wide-ranging legal liabilities. Thorough and thoughtful work performed by qualified technical experts is critically important to prevent, reduce, manage, prove, or disprove such liabilities. 


\section{Endnotes}

1 See Restatement (Second) of Torts $\S 281$ (1965).

2 Lore v. Suwanee Creek Homeowners Ass'n, Inc., 305 Ga.App. 165, 168 (Ga. Ct. App. 2010).

3 Lore v. Suwanee Creek Homeowners Ass'n, Inc., 305 Ga.App. 165, 168 (Ga. Ct. App. 2010).

4 Widner v. King County, No. C08-1170JLR, 2009 WL $2578979, * 2$ (W.D. Wash. Aug. 18, 2009).

5 Widner v. King County at $* 2$.

6 See e.g., Kowalsky v. S \& J Operating Co., 539 Fed. Appx. 908, 913 (10th Cir. 2013).

7 See generally City of Atlanta v. Hofrichter/Stiakakis, 663 S.E.2d 379, 383 (Ga. App. 2008).

8 See Hale v. Ward Co., 2014 ND 126 (N.D. 2014).

9 See e.g., Kowalsky, 539 Fed.Appx. at 915.

10 Stone Man, Inc. v. Green, 263 Ga. 470, 471-72 (1993).

11 Stone Man, Inc. v. Green at 471-72.

12 Stone Man, Inc. v. Green at 472.

13 See e.g., Stone Man, Inc. v. Green at 471-72.

14 Solebury School v. Commonwealth of Pennsylvania Dep't of Envtl. Prot. and New Hope Crushed Stone \& Lime Co., No. 2011-136-L, 2014 WL 4087592, *14 (Environmental Hearing Board July 31, 2014) (hereinafter Solebury School v. DEP)

15 Solebury School v. DEP at *16.

16 Solebury School v. DEP at *21 (quoting 52 P.S. $\S 3302)$.

17 Solebury School v. DEP at *21 (citing $25 \mathrm{~Pa}$. Code $\S 77.457(\mathrm{a}))$.

18 Solebury School v. DEP at *22.

19 Solebury School v. DEP at *24.

2052 P.S. \& 3311(b).

21 See 52 P.S. § 3311(b): 71 P.S. § 510-17(3).

22 Solebury School v. DEP at *28. 